\title{
DISTRIBUSI KEJADIAN HEPATITIS B MENURUT CAKUPAN IMUNISASI HB-0 DAN CAKUPAN K4 DI JAWA TIMUR
}

\author{
HEPATITIS B DISTRIBUTION ACCORDING TO HB-O \\ IMMUNIZATION COVERAGE AND COVERAGE OF K4 \\ IN EAST JAVA
}

\author{
Maharani Dyah Pertiwi ${ }^{1 *}$ \\ ${ }^{1}$ Jurusan Kesehatan Masyarakat, Fakultas Kesehatan Masyarakat Universitas Airlangga \\ *email: maharani.dyah.pertiwi-2016@fkm.unair.ac.id
}

\begin{abstract}
Hepatitis B is a disease that is still a public health problem. Based on WHO data in 2017, most of the world's deaths in 2015 caused quite a lot of hepatitis viruses and most were caused by the hepatitis B virus. The prevalence of hepatitis in Indonesia is considered high in the world or referred to as endemic. The coverage of Hb-O immunization in East Java except in 2015 is classified as high because it has achieved $\mathrm{Hb}-\mathrm{O}$ immunization $>90 \%$ but the incidence of Hepatitis B remains and has increased in the 3 years of 2015, 2016, and 2017. This study seeks to see the possibility of an increase in cases of Hepatitis B occurring in East Java-based on the protection of $\mathrm{Hb}-\mathrm{O}$ immunization in infants given at the age of 0-7 days and an increase in ANC 4th visit. This type of research uses descriptive-analytic design and the design of this study is a correlation study. The sample population is 38 districts/cities in East Java. Data obtained from the health profiles of East Java in 2015, 2016, and 2017. Data processing using the Health Mapper application version 4.3. The distribution of hepatitis B events against Hb-O immunization in East Java in 2015, 2016, and 2017 showed the incidence of hepatitis B increased with increasing $\mathrm{Hb}-\mathrm{O}$ immunization. The distribution of hepatitis B events with anticipation of ANC 4th visit in 2015, 2016 and 2017 shows an increase in hepatitis $B$ incidence with an increase in ANC 4th visit. Hepatitis B can occur in areas that have decreased at the time of $\mathrm{Hb}-0$ immunization and improved ANC 4th visit.
\end{abstract}

Keyword: ANC 4th visit, east java, Hb-O immunization coverage, hepatitis $B$

\begin{abstract}
Abstrak
Hepatitis B merupakan salah satu penyakit yang masih menjadi masalah kesehatan masyarakat. Berdasarkan data WHO tahun 2017, sebagian besar kematian didunia pada tahun 2015 yang disebabkan virus hepatitis cukup banyak dan yang terbanyak ialah yang disebabkan oleh virus hepatitis B (VHB). Prevalensi penyakit hepatitis di Indonesia yang termasuk tinggi di dunia atau berpotensi sebagai endemis. Cakupan imunisasi Hb-0 di Jawa Timur kecuali tahun 2015 tergolong tinggi karena telah mencapai cakupan imunisasi $\mathrm{Hb}-0>90 \%$ namun kejadian Hepatitis B tetap ada dan meningkat dalam 3 tahun periode 2015, 2016, dan 2017. Penelitian ini bertujuan untuk melihat kecenderungan peningkatan kasus Hepatitis B yang terjadi di Jawa Timur berdasarkan cakupan imunisasi $\mathrm{Hb}-0$ pada bayi yang diberikan pada umur 0-7 hari dan cakupan Kunjungan 4 Antenatal Care (ANC). Jenis penelitian ini menggunakan desain deskiriptif analitik dan rancangan penelitian ini adalah studi kolerasi. Populasi sampel sebanyak 38 kabupaten/kota di Jawa Timur. Data berasal dari profil kesehatan Jawa Timur tahun 2015, 2016, dan 2017. Pengolahan data menggunakan aplikasi Health Mapper versi 4.3. Distribusi kejadian Hepatitis B dengan cakupan imunisasi Hb-0 di Jawa Timur pada tahun 2015, 2016, dan 2017 menunjukkan kejadian hepatitis $\mathrm{B}$ meningkat dengan cakupan imunisasi $\mathrm{Hb}-0$ yang mengalami penurunan. Distribusi kejadian hepatitis B dengan cakupan kunjungan 4 ANC pada tahun 2015, 2016, dan 2017 menunjukkan peningkatan kejadian hepatitis B dengan cakupan Kunjungan 4 ANC yang menurun. Kejadian Hepatitis B cenderung terjadi pada daerah yang mengalami penurunan pada cakupan imunisasi $\mathrm{Hb}-0$ dan cakupan Kunjungan 4 ANC.
\end{abstract}

Kata Kunci : cakupan imunisasi Hb-0, hepatitis B, Jawa Timur, kunjungan 4 ANC 


\section{PENDAHULUAN}

Hepatitis merupakan salah satu penyakit menular yang masih menjadi masalah kesehatan masyarakat. Hepatitis merupakan peradangan hati yang dapat berkembang menjadi fibrosis, sirosis maupun kanker hati. Hepatitis virus menyebabkan 1,34 juta kematian pada tahun 2015, kasus kematian akibat hepatitis virus meningkat dari waktu ke waktu. Pada tahun 2015, sebagian besar kematian akibat virus hepatitis adalah penyakit hati kronis (sirosis) sebanyak 720.000 kematian dan sebanyak 470.000 kematian karena kanker hati. Jenis infeksi virus hepatitis, pada tahun 2015 di dunia diperkirakan 257 juta orang disebabkan oleh VHB dan 71 juta orang disebabkan oleh virus hepatitis C (WHO, 2017). Respon global terhadap hepatitis virus menunjukkan hasil yang baik melalui peningkatan efektif imunisasi hepatitis B. Cakupan imunisasi global hepatitis B tahun 2015 pada bayi mencapai $84 \%$. Hal ini mengurangi penularan VHB dalam lima tahun pertama kehidupan secara substansial yang dapat dilihat dari prevalensi VHB mengalami penurunan pada anak sebanyak 1,3\% (WHO, 2017). Prevalensi hepatitis di Indonesia sebesar 1,2\% pada tahun 2013. Hal ini meningkat daripada prevalensi pada tahun 2007. Rincian prevalensi masing masing jenis hepatitis adalah hepatitis A sebesar 19,3\%, Hepatitis B sebesar 21,8\% dan Hepatitis $C$ sebesar 2,5\% sehingga jenis hepatitis terbanyak adalah hepatitis B (Kementerian Kesehatan RI, 2017).

Faktor kejadian hepatitis B menurut penelitian Endah dan Wibowo pada tahun 2016 bahwa faktor risiko dari Hepatitis B adalah umur 1-4 tahun, makanan tambahan dan suplemen gizi.. suplemen gizi merupakan faktor protektif kejadian hepatitis B (Endah and Wibowo, 2016).

Pelaksanaan imunisasi aktif terhadap VHB pertama kali tahun 1971 dilakukan oleh Krugman dengan mengunakan sediaan serum yang berasal dari karier virus Hepatitis B. dilakukan pada 29 anak dan hasilnya lebih dari 15 anak berhasil terlindungi dari infeksi Hepatitis B. Pengembangan vaksin setelah imunisasi tersebut adalah menggunakan antigen lain yang digunakan untuk imunisasi aktif disebut HBsAg atau Hepatitis B Surface Antigen. Hepatitis B ditularkan melalui beberapa cara antara lain yaitu berbagi alat suntik, luka yang disebabkan oleh benda tajam, kontak seksual, dan penularan vertikal dari ibu ke anak.

Prevalensi penyakit hepatitis di Indonesia yang termasuk tinggi di dunia atau berpotensi sebagai endemis. WHO memberikan himbauan sejak tahun 1997, bahwa seluruh negara yang berpotensi sebagai endemi virus hepatitis harus memberikan imunisasi hepatitis B yang rutin. Imunisasi $\mathrm{Hb}$ pada bayi di Indonesia terdapat 4 kali pelaksanaan, antara lain pada saat lahir diberikan imunisasi hepatitis $\mathrm{Hb}-0$, ketika bayi telah berusia 2 bulan hingga 4 bulan secara berturut - turut diberikan imunisasi $\mathrm{Hb} 1$ hingga $\mathrm{Hb} 3$. Indonesia menerapkan program imunisasi Hb-0 sejak tahun 2002, namun pada pelaksanaannya masih banyak mengalami kendala sehingga hasil cakupan yang diperoleh masih rendah.

Program imunisasi $\mathrm{Hb}-\mathrm{O}$ diberikan pada bayi baru lahir 0-7 hari yang diberikan langsung di tempat pelayanan ibu bersalin. Imunisasi $\mathrm{Hb}-0$ penting diberikan karena antibodi spesifik hepatitis B ini memberikan perlindungan langsung kepada bayi. Cakupan imunisasi Hb-0 di Jawa Timur memiliki peningkatan dari tahun 2015 hingga tahun 2016, namun kembali menurun di tahun 2017. Kejadian hepatitis B dari tahun 2015 hingga 2017 pada bayi semakin meningkat di beberapa daerah di Jawa Timur (Dinas Kesehatan Jawa Timur, 2017).

Berdasarkan penelitian dari Lidia tahun 2017, terdapat hubungan antara kelengkapan imunisasi hepatitis B dengan kejadian hepatitis B (Widia, 2017). Hal ini menunjukkan bahwa, jika daerah yang memiliki cakupan imunisasi $\mathrm{Hb}-0$ yang tinggi akan berpengaruh pada kejadian hepatitis B pada bayi yang rendah. Namun pada cakupan imunisasi Hb-0 di Jawa Timur meningkat dan masih cukup tinggi. Selain penelitian tersebut, terdapat beberapa penelitian lain yaitu penelitian dari Marheanto yang menunjukkan hasil terdapat hubungan antara Kunjungan 4 ANC dengan risiko kejadian Hepatitis B pada bayi (Marhaento, 2005). Penelitian ini bertujuan untuk melihat kecenderungan peningkatan kasus Hepatitis B yang terjadi di Jawa Timur berdasarkan cakupan imunisasi $\mathrm{Hb}-0$ pada bayi yang diberikan pada umur 0-7 hari dan cakupan Kunjungan 4 ANC. 


\section{METODE}

Jenis penelitian ini menggunakan desain deskiriptif analitik. Rancangan penelitian ini adalah studi kolerasi. Populasi pada penelitian ini adalah seluruh kabupaten yang ada di Jawa Timur. Variabel pada penelitian ini terdapat 2 variabel yaitu variabel dependen dan independent. Variabel dependen pada penelitian ini adalah kejadian hepatitis B pada bayi dan variabel independent pada penelitian ini adalah cakupan imunisasi $\mathrm{Hb}-0$ yang diberikan pada usia 0-7 hari dan Kunjungan 4 ANC pada Ibu Hamil di Jawa Timur tahun 2015, 2016, dan 2017.

Data yang digunakan dalam penelitian ini adalah data sekunder yang berasal dari profil kesehatan Jawa Timur tahun 2015, 2016, dan 2017. Teknik analisis data pada penelitian ini adalah deskriptif dengan menggunakan health mapper versi 4.3..0 dengan produk versi 4.03. Aplikasi health mapper merupakan aplikasi yang dikembangkan oleh WHO dengan tujuan untuk memenuhi kebutuhan informasi surveilans penyakit menular di tingkat provinsi maupun nasional. Data yang disajikan dalam bentuk peta kejadian Hepatitis B dengan cakupan imunisasi $\mathrm{Hb}-0$ pada bayi berusia 0-7 hari dan K4 Ibu Hamil menggunakan peta distribusi wilayah Jawa Timur

\section{HASIL}

\section{Distribusi Kejadian Hepatitis B dengan Cakupan Imunisasi Hb-0}

Kejadian Hepatitis B tahun 2015 di Jawa Timur sebanyak 41 kasus dengan cakupan imunisasi sebesar 9,68\% (Dinas Kesehatan Jawa Timur, 2015). Cakupan imunisasi Hb-0 pada tahun 2015 di Jawa Timur tergolong rendah dengan rata-rata dibawah 10\%. Hanya pada Kota Malang yang cakupan imunisasi $\mathrm{Hb}-0$ sangat tinggi yaitu (lebih dari 90\%) yaitu 98,84\%. Berdasarkan kejadian Hepatitis B yang telah tercatat di Profil Kesehatan Jawa Timur 2015 adalah 4 daerah yang terdapat kasus Hepatitis B, daerah tersebut antara lain Pacitan sebesar 7 kasus dengan cakupan imunisasi Hb-0 sebesar 7,59\%, Jombang sebesar 5 kasus dengan cakupan imunisasi $\mathrm{Hb}-0$ sebesar 7\%, Pamekasan sebesar 2 kasus dengan cakupan imunisasi HB-0 sebesar 7,35\%, Kota Madiun sebesar 27 kasus dengan cakupan imunisasi HB-0 sebesar 7,35\%. Sedangkan daerah lain yang tidak terdapat kasus juga masih memiliki cakupan imunisasi $\mathrm{Hb}-0$ yang rendah.

Kejadian Hepatitis B tahun 2016 di Jawa Timur mengalami peningkatan dibandingkan tahun 2015, yaitu dari 41 kasus menjadi 432 kasus (Dinas Kesehatan Jawa Timur, 2016). Peningkatan kasus ini berbanding terbalik dengan cakupan imunisasi $\mathrm{Hb}-0$ tahun 2016 yang mengalami peningkatan secara signifikan diseluruh kabupaten/kota di Jawa Timur. Cakupan imunisasi Hb-0 tahun 2016 mengalami peningkatan dari $9,68 \%$ menjadi sebesar $94,5 \%$. Berdasarkan profil kesehatan Jawa Timur tahun 2016, terdapat 7 daerah yang mengalami kejadian Hepatitis B yaitu Ponorogo sebesar 6 kasus dengan cakupan imunisasi Hb-0 sebesar 91,6\%, Kabupaten Jombang sebesar 1 kasus dengan cakupan imunisasi Hb-0 sebesar 90,39\%, Kabupaten Nganjuk sebesar 6 kasus dengan cakupan imunisasi Hb-0 sebesar 59,48\%, Kabupaten Sampang sebesar 2 kasus dengan cakupan imunisasi $\mathrm{Hb}-0$ sebesar 96,71\%, Kota Malang sebesar 181 kasus dengan cakupan imunisasi Hb-0 sebesar 99,23\%, Kota Madiun sebesar 17 kasus dengan cakupan imunisasi Hb-0 sebesar 151,07\% dan Kota Surabaya sebesar 219 kasus dengan cakupan imunisasi Hb-0 sebesar 86,07\%. Sebanyak 5 daerah yang cakupan imunisasi $\mathrm{Hb}-0$ diatas 90\% namun masih ditemukan kasus Hepatitis B dan sebanyak 2 daerah yang cakupan imunisasi Hb-0 dibawah 90\% dan ditemukan kasus Hepatitis B adalah Kabupaten Nganjuk dan Kota Surabaya.

Kejadian Hepatitis B tahun 2017 di Jawa Timur sebanyak 1287 kasus dengan cakupan imunisasi Hb-0 sebesar 90,63\% (Dinas Kesehatan Jawa TImur, 2017). Cakupan imunisasi $\mathrm{Hb}-0$ mengalami penurunan dari $94,5 \%$ menjadi $90,63 \%$ dan kasus hepatitis B mengalami peningkatan dari 432 kasus menjadi 1287 kasus. Berdasarkan Profil Kesehatan Jawa Timur tahun 2017 terdapat 6 daerah yang terdapat kasus Hepatitis B antara lain Ponorogo mengalami peningkatan kasus Hepatitis B dari 6 kasus menjadi 36 kasus dengan cakupan imunisasi $\mathrm{Hb}-0$ yang mengalami penurunan dari $91,6 \%$ menjadi $87,89 \%$, Tulungagung sebesar 19 kasus dengan 
cakupan imunisasi $\mathrm{Hb}-0$ sebesar 85,43\%, Situbondo sebesar 7 kasus dengan cakupan imunisasi Hb-0 sebesar 96,93\%, Sampang mengalami peningkatan kasus dari 2 kasus menjadi 52 kasus dengan cakupan imunisasi $\mathrm{Hb}-0$ yang mengalami penurunan dari $96,71 \%$ menjadi $66,90 \%$, Kota Madiun mengalami peningkatan kasus dari 17 kasus menjadi 19 kasus dengan cakupan imunisasi $\mathrm{Hb}-0$ yang menurun dari $151,07 \%$ menjadi $70,73 \%$, dan Kota Surabaya juga mengalami peningkatan kasus dari 219 kasus menjadi 1154 kasus dengan cakupan imunisasi $\mathrm{Hb}-0$ yang mengalami peningkatan dari $86,07 \%$ menjadi $94,2 \%$. Kasus tersebut melonjak sangat tinggi terutama pada Kota Surabaya.

\section{Distribusi Kejadian Hepatitis B dengan K4 ANC}

Kejadian Hepatitis B tahun 2015 di Jawa Timur sebanyak 41 kasus dengan cakupan Kunjungan 4 ANC sebesar 91,24\%. Kejadian Hepatitis B tahun 2015 di Jawa Timur antara lain di Kabupaten Pacitan sebanyak 7 kasus dengan cakupan Kunjungan 4 ANC sebesar 82,94\%, Kabupaten Jombang sebanyak 5 kasus dengan cakupan Kunjungan 4 ANC sebesar 91,41\%, Kabupaten Pamekasan sebanyak 2 kasus dengan cakupan Kunjungan 4 ANC sebesar 93,82\%, Kota Madiun sebanyak 27 kasus dengan cakupan Kunjungan 4 ANC sebesar 97,15\%. Berdasarkan hasil tersebut, daerah yang memiliki cakupan Kunjungan 4 ANC dibawah 90\% mengalami kejadian Hepatitis B, namun terdapat beberapa kejadian kasus Hepatitis B yang memiliki cakupan Kunjungan 4 ANC lebih dari 90\% seperti pada Kabupaten Pamekasan, Kabupaten Jombang dan Kota Madiun.

Kejadian Hepatitis B tahun 2016 di Jawa Timur sebanyak 432 kasus dengan cakupan Kunjungan 4 ANC sebesar 89,5\%. Kasus Hepatitis B tahun 2016 mengalami peningkatan daripada tahun 2015 dan cakupan Kunjungan 4 ANC mengalami penurunan daripada tahun 2015 Kejadian Hepatitis B tahun 2016 di Jawa Timur antara lain di Kabupaten Ponorogo sebanyak 6 kasus dengan cakupan Kunjungan 4 ANC sebesar $84,80 \%$, Kabupaten Jombang sebanyak 1 kasus dengan cakupan Kunjungan 4 ANC sebesar 89,3\%, Kabupaten Nganjuk sebanyak 6 kasus dengan cakupan Kunjungan 4 ANC sebesar
81,6\%, Kabupaten Sampang sebanyak 2 kasus dengan cakupan Kunjungan 4 ANC sebesar 83,9\%, Kota Madiun sebanyak 17 kasus dengan cakupan Kunjungan 4 ANC sebesar 97,8 \%, Kota Malang sebanyak 181 kasus dengan cakupan Kunjungan 4 ANC sebesar 88,6\% dan Kota Surabaya sebanyak 219 kasus dengan cakupan Kunjungan 4 ANC sebesar 98,5\% . Berdasarkan hasil tersebut, rata - rata daerah yang memiliki cakupan Kunjungan 4 ANC dibawah 90\% mengalami kejadian Hepatitis B.

Kejadian Hepatitis B tahun 2017 di Jawa Timur sebanyak 1287 kasus dengan cakupan Kunjungan 4 ANC sebesar 89,9\%. Kasus Hepatitis B tahun 2017 mengalami peningkatan daripada tahun 2016 dan cakupan Kunjungan 4 ANC mengalami peningkatan daripada tahun 2016. Kejadian Hepatitis B tahun 2016 di Jawa Timur antara lain di Kabupaten Ponorogo memiliki kasus sebanyak 36 kasus dengan cakupan Kunjungan 4 ANC sebesar 83,2\%, cakupan tersebut mengalami penurunan dari tahun 2016 yang mengakibatkan peningkatan pada kasus Hepatitis B, Kabupaten Tulungagung memiliki kasus sebanyak 19 kasus dengan cakupan Kunjungan 4 ANC sebesar 90,3\%, Kabupaten Situbondo memiliki kasus sebanyak 7 kasus dengan cakupan Kunjungan 4 ANC sebesar 88\%, Kabupaten Sampang memiliki kasus sebanyak 52 kasus dengan cakupan Kunjungan 4 ANC sebesar $84,9 \%$, Kota Madiun memiliki kasus sebanyak 19 kasus dengan cakupan Kunjungan 4 ANC sebesar 99,6\% dan Kota Surabaya memiliki kasus sebanyak 1152 kasus dengan cakupan Kunjungan 4 ANC sebesar 98,5\%. Berdasarkan hasil tersebut, meskipun terjadi peningkatan pada cakupan kunjungan 4 ANC namun pada Kota Madiun dan Kota Surabaya tetap mengalami peningkatan pada kasus Hepatitis B.

\section{PEMBAHASAN}

\section{Distribusi Kejadian Hepatitis B dengan Cakupan Imunisasi Hb-0}

Hasil distribusi kejadian Hepatitis B dengan cakupan imunisasi $\mathrm{Hb}-0$ pada bayi tahun 2015, 2016, 2017 di Jawa Timur menunjukkan bahwa kejadian hepatitis B cenderung meningkat setiap tahunnya dengan cakupan imunisasi $\mathrm{Hb}-0$ yang fluktuatif . 
Peningkatan jumlah ibu hamil dengan hepatitis B pada tahun 2016 dan 2017 disebabkan oleh pendeteksian yang semakin canggih. Kemenkes menyampaikna bahwa mulai tahun 2016 hepatitis B telah dideteksi dilakukan dengan Rapid Diagnostic Test (RDT) Hepatitis B surface Antigen (HBsAg) (Kemenkes, 2019).

Imunisasi $\mathrm{Hb}-0$ diberikan untuk meningkatkan kekebalan tubuh anak terhadap penyakit hepatitis B. imunisasi $\mathrm{Hb}$ 0 juga diberikan untuk mencegah penularan penyakit dari ibu yang terinfeksi kepada bayinya dan mencegah penularan penyakit tertentu selama beberapa bulan pertama sejak lahir dari orang yang terinfeksi di 2015 2016
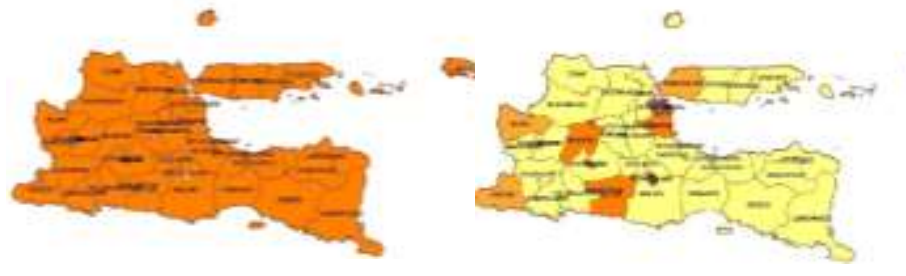

rumah yang sama atau orang lain yang mungkin terinfeksi (Departmen of Health, 2013). Imunisasi Hepatitis B dilakukan setelah bayi lahir kurang dari 24 jam, bayi berumur 2 bulan, 3 bulan dan 4 bulan.

Vaksin merupakan produk biologis yang terdiri dari komponen virus yang telah dilemahkan atau dimatikan untuk merangsang pembentukan kekebalan tubuh. Vaksin yang mencegah infeksi virus Hepatitis B lebih dari $95 \%$ menetap minimal sampai dengan 12 tahun pasca imunisasi (Widia, 2017). Vaksin Hepatitis B perlu diberikan kepada bayi karena tubuh bayi masih belum sebaik orang dewasa sehingga bayi mudah terpapar infeksi hepatitis B.

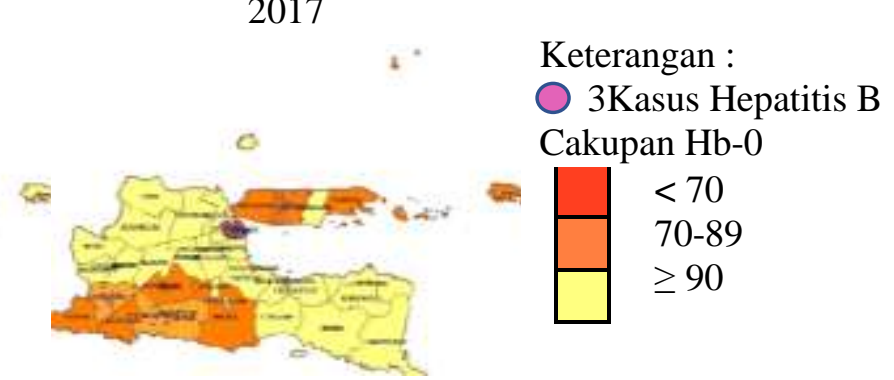

Gambar 1. Distribusi Kejadian Hepatitis B dengan Cakupan Imunisasi Hb-0 Tahun 2015, 2016, 2017 di Jawa Timur

2015

Q

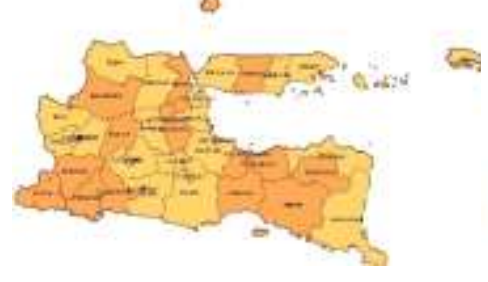

2016

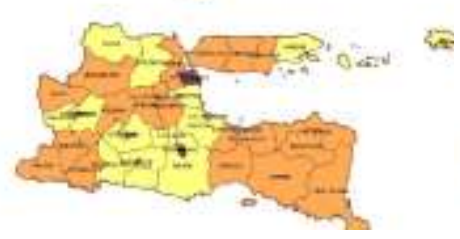

2017

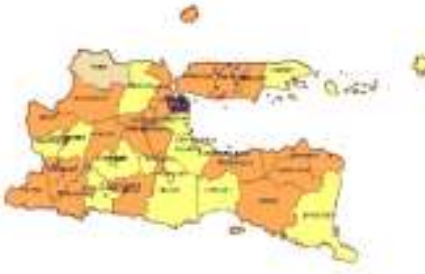

Keterangan :

O 3 Kasus Hepatitis B Cakupan K4 ANC

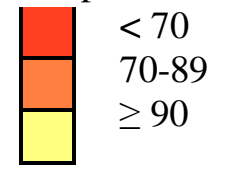

Gambar 2. Distribusi Kejadian Hepatitis B dengan Cakupan Kunjungan 4 ANC Tahun 2015, 2016, 2017 di Jawa Timur
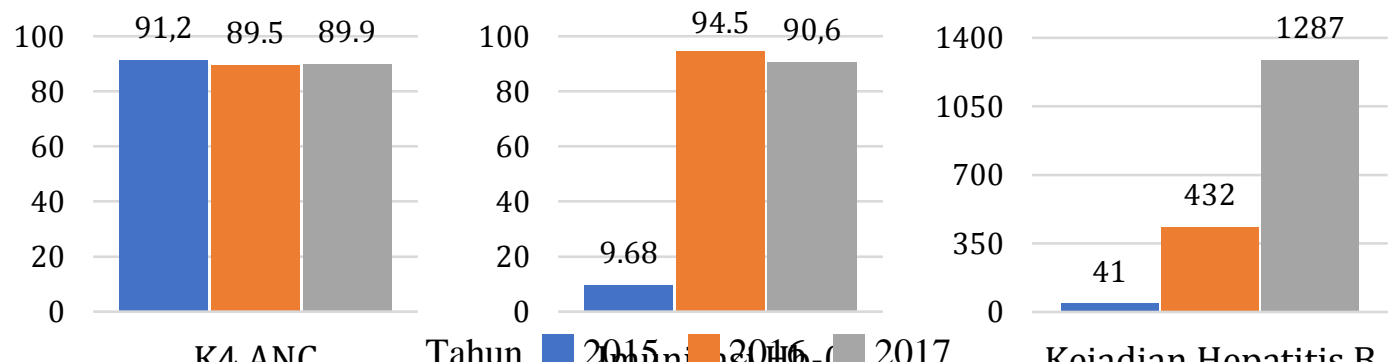

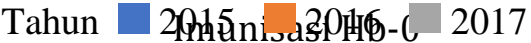

Kejadian Hepatitis B

Gambar 3. Frekuensi Cakupan Imunisasi dan Kunjungan 4 ANC dengan Kejadian Hepatitis B Tahun 2015, 2016, dan 2017 di Jawa Timur 


\section{Distribusi Kejadian Hepatitis B dengan Cakupan K4 ANC}

Distribusi kejadian Hepatitis B dengan cakupan Kunjungan 4 ANC di Jawa Timur pada tahun 2015, 2016 dan 2017 menunjukkan kejadian Hepatitis B mengalami peningkatan dari tahun sebelumnya dan diikuti dengan cakupan Kunjungan 4 ANC yang mengalami penurunan dari tahun 2015 ke tahun 2016, dan mengalami sedikit peningkatan di tahun 2017. Standar pemeriksaan ANC di Indonesia sejumlah 4 kali pemeriksaan. K4 atau Kunjungan 4 ANC penting karena Kunjungan 4 diperlukan Ibu hamil untuk mencegah terjadinya risiko maupun mengatasi risiko yang akan dihadapi Ibu saat melahirkan. Ibu Hamil akan mengetahui memiliki risiko - risiko tertentu setelah melakukan kunjungan ANC. Selain itu, Kunjungan 4 juga dapat mengindentifikasi terjadinya penyulit selama kehamilan dan persalinan sehingga dapat dicegah dan diatasi secara dini (Noor, 2012).

Ibu hamil yang terkena Hepatitis B seringkali tidak mengetahui bahwa sedang terkena penyakit, hal ini dapat membahayakan jiwa Ibu dan bayi yang dikandungnya, karena penularan Hepatitis B dapat terjadi melalui Mother-to-ChildTransmission (MTCT) (Pusparini and Ayu, 2017). MTCT teradi dari seorang ibu hamil yang menderita Hepatitis B akut kepada bayi yang dikandungnya atau dilahirkannya. Adanya ANC dapat memberikan deteksi dini dengan melakukan laboratorium sampel darah pada ibu hamil sesuai dengan T8 pada pelayanan antenatal terpadu lengkap.

Cakupan Imunisasi dan Cakupan K4 ANC tahun 2015, 2016, dan 2017 dengan Kejadian Hepatitis B di Jawa Timur

Cakupan imunisasi Hepatitis B yang tinggi tidak menjamin terbebasnya daerah tersebut dari kejadian Hepatitis B, seperti pada beberapa daerah yang memiliki cakupan imunisasi tinggi namun masih adanya kejadian Hepatitis B yaitu pada tahun 2016 di Kota Malang yang memiliki cakupan imunisasi 99,23\% namun masih ditemukan 181 kasus. Selain itu, terdapat beberapa daerah yang memiliki cakupan tinggi namun masih ditemukan kejadian Hepatitis B antara lain pada tahun 2016 di
Kabupaten Ponorogo, Kabupaten Jombang, Kabupaten Sampang, dan Kota Madiun. Pada tahun 2017, terdapat di Kabupaten Situbondo, dan Kota Batu. Cakupan imunisasi yang tinggi tidak menjamin terbebas dari penyakit tersebut, hal ini disebabkan oleh beberapa faktor antara lain kegagalan terbentuknya antibodi yang dimiliki oleh bayi atau antibody maternal, pemberian imunisasi yang tidak efektif, penurunan kualitas vaksin (Harahap, 2016).

Kejadian Hepatitis B pada tahun 2015 di Jawa Timur pada daerah yang memiliki cakupan Kunjungan 4 ANC yang rendah yaitu Kabupaten Pacitan, pada tahun 2016 daerah yang memiliki kejadian Hepatitis B dan cakupan Kunjungan 4 ANC yang rendah yaitu Ponorogo, Jombang, Nganjuk, Sampang, dan Kota Malang serta pada tahun 2017 terdapat Ponorogo, Situbondo, dan Sampang. Kota Surabaya memiliki cakupan Kunjungan 4 ANC dan cakupan imunisasi $\mathrm{Hb}-0$ yang tinggi tetap terdapat kejadian Hepatitis B.

Perbandingan kejadian Hepatitis B dari tahun 2015 ke tahun 2016 antara lain pada Kota Madiun mengalami penurunan kejadian Hepatitis B dengan mengalami peningkatan pada cakupan Kunjungan 4 ANC, Kabupaten Jombang mengalami penurunan dengan cakupan imunisasi yang mengalami peningkatan, Kabupaten Pacitan mengalami penurunan hingga tidak ada kasus pada tahun 2016 dengan cakupan imunisasi yang mengalami peningkatan, dan Kabupaten Pamekasan yang mengalami penurunan hingga tidak ada kasus pada tahun 2016 dengan cakupan imunisasi mengalami peningkatan. Perbandingan kejadian Hepatitis B dari tahun 2016 ke tahun 2017 antara lain Kabupaten Ponorogo mengalami peningkatan kasus dibandingkan dengan tahun 2016 dengan mengalami penurunan pada cakupan imunisasi $\mathrm{Hb}-0$ dan cakupan Kunjungan 4 ANC, Kabupaten Tulungagung pada tahun 2017 terdapat kejadian hepatitis B padahal pada tahun 2016 tidak ada kejadian hepatitis B dengan diikuti penurunan pada cakupan imunisasi $\mathrm{Hb}-0$ dan penurunan pada cakupan Kunjungan 4 ANC, Kabupaten Nganjuk mengalami penurunan kasus hingga tidak ada kasus pada tahun 2017 dengan mengalami peningkatan pada cakupan 
imunisasi Hb-0, Kabupaten Jombang mengalami penurunan hingga idak terdapat kasus pada tahun 2017 dengan mengalami peningkatan pada cakupan imunisasi $\mathrm{Hb}-0$, Kabupaen Sampang mengalami peningkatan kasus dengan mengalami penurunan pada cakupan imunisasi $\mathrm{Hb}-0$ dan Kabupaten Madiun mengalami peningkatan kasus diikuti dengan penurunan cakupan imunisasi $\mathrm{Hb}-0$. Beberapa daerah meskipun memiliki cakupan imunisasi $\mathrm{Hb}-0$ dan cakupan Kunjungan 4 ANC yang tinggi, namun masih terdapat kasus hepatitis B, daerah tersebut adalah kota Surabaya. Kunjungan ANC secara rutin sebanyak 4 kali kunjungan dapat mencegah komplikasi yang terjadi saat melahirkan dan risiko yang akan dihadapi bayi saat lahir, dan pemeriksaan ANC dapat menyaring Ibu yang tidak mengetahui bahwa Ibu telah terkena penyakit yang berbahaya seperti Hepatitis B (Bukit, 2019).

Cakupan imunisasi yang rendah dapat disebabkan oleh beberapa faktor yang berasal dari Ibu. Beberapa penelitian mengenai hal tersebut antara lain penelitian dari Surhati, Suryani, dan Yuli Suryanti tahun 2013 mengenai faktor yang berhubungan dengan perilaku Ibu dalam pemberian Imunisasi $\mathrm{Hb}-0$ didapatkan hasil terdapat hubungan antara kepercayaan ibu dengan pemberian Imunisasi $\mathrm{Hb}-0$ dengan $\mathrm{P}$ value $0,001<0,05$ sehingga hubungan tersebut signifikan (Suharti et al., 2013). Penelitian lain dari Reni tahun 2016, menunjukkan hasil bahwa terdapat hubungan sikap Ibu dengan Pemberian imunisasi Hb-0 dengan Pvalue 0,01<0,05 yang berarti memiliki hubungan yang signifikan, terdapat hubungan fasilitas pelayanan kesehatan dengan pemberian imunisasi Hb-0 dengan Pvalue 0,0005<0,05 dan terdapat hubungan dukungan tokoh masyarakat dengan pemberian imunisasi $\mathrm{Hb}-0$ dengan Pvaluue 0,01<0,05 artinya hubungan yang signifikan (Harahap, 2016). Penelitian dari Titis tahun 2014 bahwa pengetahuan Ibu memiliki hubungan dengan melakukan kunjungan ANC (Purboningsih, 2014). Sehingga dengan meningkatkan pengetahuan Ibu mengenai program ANC dapat mencegah berbagai risiko termasuk kejadian Hepatitis B.

Peta distribusi kejadian Hepatitis B menunjukkan setiap penurunan imunisasi $\mathrm{Hb}-0$ dan cakupan Kunjungan 4 ANC menyebabkan peningkatan kasus Hepatitis B. Namun, terdapat beberapa daerah yang memiliki cakupan imunisasi $\mathrm{Hb}-0$ yang tinggi dan K4 ANC yang tinggi masih terdapat kasus Hepatitis B dan terdapat daerah yang memiliki cakupan imunisasi yang menurun namun tidak berpengaruh pada peningkatan kejadian Hepatitis B. Tingkat pengetahuan Ibu memiliki hubungan dengan status imunisasi $\mathrm{Hb}-0$ dengan Pvalue sebesar 0,026<0,05. Berdasarkan hal tersebut pengetahuan ibu sangat berpengaruh terhadap keberhasilan pemberian imunisasi $\mathrm{Hb}-0$ (Pontolawokang et al., 2016). Kurangnya cakupan imunisasi $\mathrm{Hb}-0$ pada bayi lahir 0-7 hari disebabkan beberapa faktor antara lain terdapat persalinan yang ditolong bukan oleh tenaga kesehatan yang professional bahkan ada yang tidak ditolong oleh tenaga kesehatan seperti ibu melahirkan sendiri, dibantu oleh dukun dan lain sebagainya sehingga saat ketika lahir tidak diberikan imunisasi Hb-0. Selain itu, kurangnya cakupan imunisasi $\mathrm{Hb}$ 0 pada bayi 0-7 hari dipengaruhi oleh kelengkapan fasilitas kesehatan pada pelayanan kesehatan setempat (Pontolawokang et al., 2016).

Cakupan imunisasi $\mathrm{Hb}-0$ dan Kunjungan 4 ANC dipengaruhi oleh faktor predisposing, enabling, dan reinforcing. Faktor predisposing antara lain yaitu tingkat pengetahuan, sikap, kepercayaan, keyakinan Ibu. Semakin tinggi faktor predisposing pada Ibu, semakin tinggi pula kewaspadaan dan kesadaran Ibu mengenai kesehatn dan kemungkinan beserta risiko yang akan terjadi dikemudian hari sehingga dapat mendorong Ibu melakukan imunisasi dan pemeriksaan ANC. Faktor enabling antara lain pelayanan kesehatan, transportasi, jarak, dan biaya. Semakin baik pelayanan kesehatan dan keterjangkauan transportasi, jarak, dan biaya akan semakin menunjang kesehatan masyarakat dan dapat menekan morbiditas dan mortalitas pada daerah tersebut. Faktor penguat (reinforcing) antara lain peran petugas kesehatan dan dukungan tokoh masyarakat. Dukungan tokoh masyarakat diperlukan untuk menumbuhkan kesadaran masyarakat karena pembuatan perundang - undangan tentang berperilaku sehat tidak akan efektif jika berdiri sendiri (Harahap, 2016). 


\section{KESIMPULAN DAN SARAN Kesimpulan}

Kejadian Hepatitis B cenderung terjadi pada wilayah dengan cakupan imunisasi $\mathrm{Hb}-$ 0 yang rendah dan didukung dengan cakupan Kunjungan 4 ANC yang cenderung mengalami penurunan dari tahun sebelumnya. Meskipun terdapat beberapa daerah yang tetap ditemukan kejadian Hepatitis B dengan cakupan Kunjungan 4 dan ANC yang tinggi dan juga terdapat daerah yang tetap tidak ditemukan kejadian Hepatitis B meskipun cakupan imunisasi $\mathrm{Hb}-0$ cenderung rendah dan cakupan Kunjungan 4 ANC cenderung mengalami penurunan dari tahun sebelumnya. Kunjungan 4 ANC cenderung dapat mencegah kejadian Hepatitis B di Jawa Timu. Kunjungan ANC berfungsi untuk mencegah dan mendeteksi dini risiko yang akan terjadi saat persalinan maupun setelah bayi dilahirkan. Adanya Kunjungan ANC juga dapat meningkatkan pengetahuan Ibu mengenai mencegah dan mengatasi risiko. Sehingga imunisasi $\mathrm{Hb}-0$ dan Kunjungan 4 ANC jika dilaksanakan dengan baik dan benar dapat meningkatkan keefektifan dalam mencegah kejadian Hepatitis B..

\section{Saran}

Saran bagi peneliti selanjutnya sebagai evaluasi dan meneliti lebih lanjut mengenai hubungan secara statistic mengenai kejadian hepatitis B dan cakupan K4. Saran bagi Dinas Kesehatan Jawa Timur sebagai bahan masukkan dan pertimbangan, perencanaan, pelaksanaan serta evaluasi program imunisasi dasar khususnya imunisasi hepatitis B 0-7 hari dan bagi Puskesmas yang berada di Jawa Timur diharapkan dapat menjadi bahan informasi bagi pengelola program serta penyuluhan lebih lanjut mengenai imunisasi hepatitis B 0-7 hari dalam wilayah kerja.

\section{DAFTAR RUJUKAN}

1] Bukit, R. 2019. Hubungan Pemeriksaan Kehamilan K4 dengan Kejadian Kehamilan Resiko Tinggi pada Ibu Hamil Trimester III. Jurnal Endurance 4, 199.

2] Departmen of Health. 2013. Hepatitis B pada Bayi. Victoria, Melbpurne.
3] Dinas Kesehatan Jawa Timur. 2015. Profil Kesehatan Jawa Timur tahun 2015. Surabaya.

4] Dinas Kesehatan Jawa Timur. 2016. Profil Kesehatan Jawa Timur tahun 2016. Surabaya.

5] Dinas Kesehatan Jawa Timur. 2017. Profil Kesehatan Jawa Timur tahun 2017. Surabaya.

6] Endah, N., Wibowo. 2016. FaktorFaktor yang Berhubungan dengan Tingkat Kekebalan Hepatitis B (antiHBs) pada Anak Umur 1-14 Tahun dari Data Hasil Riskesdas 2007. Media Penelitian dan Pengembangan Kesehatan 26, 59-64.

7] Harahap, R.A. 2016. Pengaruh Faktor Predisposing, Enabling dan Reinforcing Terhadap Pemberian Imunisasi Hepatitis B pada Bayi Di Puskesmas Bagan Batu Kecamatan Bagan Sinembah Kabupaten Rokan Hilir. Jurnal Ilmiah Penelitian Kesehatan. Fakultas Kesehatan Masyarakat Universitas Islam Negeri Sumatera Utara 1, 79-103.

8] Kemenkes. 2019. 1,5 Juta Lebih Ibu Hamil Dideteksi Dini Hepatitis B. URL https://www.kemkes.go.id/article/view /19072300002/1-5-juta-lebih-ibuhamil-dideteksi-dini-hepatitis-b.html

9] Kementerian Kesehatan RI. 2017. Infodatin Situasi Hepatitis $B$ di Indonesia Tahun 2017. Kementerian Kesehatan Republik Indonesia, Jakarta.

10] Marhaento, S.H. 2005. Faktor-Faktor Risiko yang Berpengaruh Terhadap Vaksinasi Hepatitis B-1 pada Bayi Umur $\leq 7$ Hari (Studi kasus di Kabupaten Demak dan Temanggung) 1-7.

11] Noor, L. 2012. Hubungan Frekuensi Kunjungan ANC Selama Kehamilan Dengan Kejadian Kematian Neonatal. Universitas Indonesia.

12] Pontolawokang, A., Korah, B., Dompas, R. 2016. Faktor-Faktor Yang Mempengaruhi Pemberian Imunisasi Hepatitis B 0. Jurnal Ilmiah Bidan 4, 31-37.

13] Purboningsih, T. 2014. Hubungan 
Pengetahuan Ibu Hamil Tentang ANC (Antenatal Care). Kesehatan 1-13.

14] Pusparini, A.D., Ayu, P.R. 2017. Tatalakasana Persalinan pada Kehamilan dengan Hepatitis B. Jurnal Kedokteran Universitas Lampung 7, 15.

15] Suharti, Suryani, Suryanti, Y. 2013. Analisis Faktor - Faktor yang Berhubungan dengan Perilaku Ibu Dalam Pemberian Imunisasi Hepatitis
B 0-7 Hari. Jurnal Kesehatan IV, 5359.

16] WHO. 2017. Global hepatitis report in 2017. World Health Organization, France.

17] Widia, L. 2017. Status Kelengkapan Imunisasi Hepatitis B pada Usia 0-6 Bulan dengan Kejadian Hepatitis B. Jurnal Ilmiah Manuntung 3, 52-58. 